\title{
Health Technology Assessment Report on Vagus Nerve Stimulation in Drug-Resistant Epilepsy
}

\author{
Carlo Efisio Marras ${ }^{1, *}$, Gabriella Colicchio ${ }^{2}{ }^{(0)}$, Luca De Palma ${ }^{3}$, Alessandro De Benedictis ${ }^{1}$, \\ Giancarlo Di Gennaro ${ }^{4}\left(\mathbb{D}\right.$, Marilou Cavaliere ${ }^{1,5}$, Elisabetta Cesaroni ${ }^{6}$, Alessandro Consales ${ }^{7}$, \\ Sofia Asioli ${ }^{8}$, Massimo Caulo ${ }^{9}$, Flavio Villani ${ }^{10}$ and Nelia Zamponi ${ }^{6}$ \\ 1 Neurosurgery Unit, Department of Neuroscience, IRCCS Bambino Gesù Children Hospital, \\ 00165 Rome, Italy; alessandro.debenedictis@opbg.net (A.D.B.); marilou.cavaliere@opbg.net (M.C.) \\ 2 Department of Neurosurgery, UCSC Gemelli University Hospital, 00167 Rome, Italy; \\ colicchiogabriella@gmail.com \\ 3 Pediatric Neurology Unit, Department of Neuroscience, IRCCS Bambino Gesù Children Hospital, \\ 00165 Rome, Italy; luca.depalma@opbg.net \\ 4 Neurology Unit, IRCCS Neuromed Institute, 86077 Pozzilli, Italy; gdigennaro@neuromed.it \\ 5 Institute of Neurosurgery, University of Milan Bicocca, 20900 Milan, Italy \\ 6 Pediatric Neurology Unit, Salesi Children Hospital, 60123 Ancona, Italy; \\ elisabetta.cesaroni@ospedaliriuniti.marche.it (E.C.); nelia.zamponi@gmail.com (N.Z.) \\ 7 Pediatric Neurosurgery Unit, G. Gaslini Hospital, 16147 Genoa, Italy; alessandroconsales@gaslini.org \\ 8 Department of Biomedical and Neuromotor Sciences, Section of Anatomic Pathology, Bellaria Hospital, \\ University of Bologna, 40139 Bologna, Italy; sofia.asioli3@unibo.it \\ 9 Department of Neuroscience, Imaging and Clinical Sciences, University of Chieti, 66100 Chieti, Italy; \\ caulo@unich.it \\ 10 Division of Clinical Neurophysiology and Epilepsy Center, IRCCS, San Martino Hospital, 16132 Genoa, Italy; \\ flavio.villani@hsanmartino.it \\ * Correspondence: carloefisio.marras@opbg.net
}

Received: 5 July 2020; Accepted: 13 August 2020; Published: 24 August 2020

\begin{abstract}
Background: Vagus nerve stimulation (VNS) is a palliative treatment for medical intractable epileptic syndromes not eligible for resective surgery. Health technology assessment (HTA) represents a modern approach to the analysis of technologies used for healthcare. The purpose of this study is to assess the clinical, organizational, financial, and economic impact of VNS therapy in drug-resistant epilepsies and to establish the congruity between costs incurred and health service reimbursement. Methods: The present study used an HTA approach. It is based on an extensive detailed bibliographic search on databases (Medline, Pubmed, Embase and Cochrane, sites of scientific societies and institutional sites). The HTA study includes the following issues: (a) social impact and costs of the disease; (b) VNS eligibility and clinical results; (c) quality of life (QoL) after VNS therapy; (d) economic impact and productivity regained after VNS; and (e) costs of VNS. Results: Literature data indicate VNS as an effective treatment with a potential positive impact on social aspects and on quality of life. The diagnosis-related group (DRG) financing, both on national and regional levels, does not cover the cost of the medical device. There was an evident insufficient coverage of the DRG compared to the full cost of implanting the device. Conclusions: VNS is a palliative treatment for reducing seizure frequency and intensity. Despite its economic cost, VNS should improve patients' quality of life and reduce care needs.
\end{abstract}

Keywords: vagus nerve stimulation; health technology assessment; drug-resistant epilepsy 


\section{Background}

Epilepsy is one of the most common neurological diseases [1]. According to World Health Organization data (WHO) [2], epilepsy affects about 50 million people worldwide, with approximately 6 million in Europe, and around 500,000 in Italy. Every year, more than 80 people per 100,000 receive a diagnosis of epilepsy, most commonly during adolescence. Epilepsy represents $0.5 \%$ of the global burden of disease and has significant economic implications in terms of healthcare needs, welfare, premature death, and work productivity loss [3]. Social stigma that surround this condition worldwide are often more difficult to overcome than seizure itself $[2,4]$.

Resective surgery is effective in selected patients with focal drug-resistant epilepsy. The results collected in both adults and children show a seizure freedom ranging between $40 \%$ and $90 \%$ [5-9]. In 1997 the Food and Drug Administration (FDA) and the agencies of the European and Canadian registration approved VNS as an additional therapy to reduce seizure frequency in adults, adolescents and children whose seizures are refractory to antiseizure drugs (ASDs) and who are not eligible for resective surgery. VNS is a neuromodulation approach that uses a surgically implantable, programmable pulse generator powered by a battery connected to a helical bipolar lead. The lead is attached to the mid cervical portion of the left vagus nerve and delivers a biphasic current that continuously cycles between on and off periods [10-13]. Studies of VNS efficacy showed, in up to $60 \%$ of implanted patients, a seizure frequency reduction higher than $50 \%$ both in adults and pediatric population [14-20]. The decrease in seizure frequency results in a reduction in hospitalization rate, recovery time and emergency hospital admissions, and consequentially in a reduction in hospital, health and social costs [21-24].

Health technology assessment (HTA) is the bridge between science that produces evidence and decisions that may derive from evidence at different levels of healthcare system provision $[5,25]$. The concept of health technology is wide and covers the entire healthcare process, including diagnosis and treatments. Evidence can impact safety and efficacy as well as the organizational, social and ethical aspects of health technology [26]. Decision-making occurs on three levels. The macro level involves policy decisions. The meso level involves decisions by the regions or individual institutions (hospitals and health trusts). The micro level involves clinical practice [27]. If the evidence to produce is organizational-managerial and the decisions to take are at micro level as they concern clinical practice, decision-makers can benefit from a process that pinpoints diagnostic-therapeutic work-up and quantifies the relative costs. The purpose of this HTA report is to assess the clinical, organizational, financial and economic impact of managing of patients with drug-resistant epilepsy. The main aim of the report is to establish the congruity between costs incurred and health service reimbursement for the management of patients with drug-resistant epilepsy treated with VNS therapy.

\section{Methods}

The present report is based on an extensive detailed bibliographic search on databases, such as Medline, Pubmed, Embase and Cochrane; sites of scientific societies; sites of institutions, such as the Italian Ministry of Health, FDA—Food \& Drug Administration, and NICE-National Institute for Clinical Excellence; institutional sites of international HTA agencies: International Network of Agencies for Health Technology Assessment (INAHTA), Canadian Agencies for Drugs and Technologies in Health (CADTH), and National Coordinating Center for Health Technology Assessment (NCCHTA) —administration regions; and gazettes. Analysis related to costs is crucial to the economic assessment and it may turn out to be a useful tool to solve specific problems when choosing among available alternatives. The analysis of relevant literature was conducted using the following key words: "HTA", “VNS", "VNS costs", “Epilepsy costs", "HTA Epilepsy", "Epilepsy social impact". The rough selection using the terms HTA and VNS included a huge number of articles. Then, matching "HTA" with "VNS", "Epilepsy", and "Epilepsy costs", the number of papers reduced substantially from 53686 (HTA only) to 303 . Most of the 303 papers selected were not focused on this issue, and very rarely analyzed epilepsy surgery; therefore, 17 contributions were considered eligible for this study (Figure 1). 


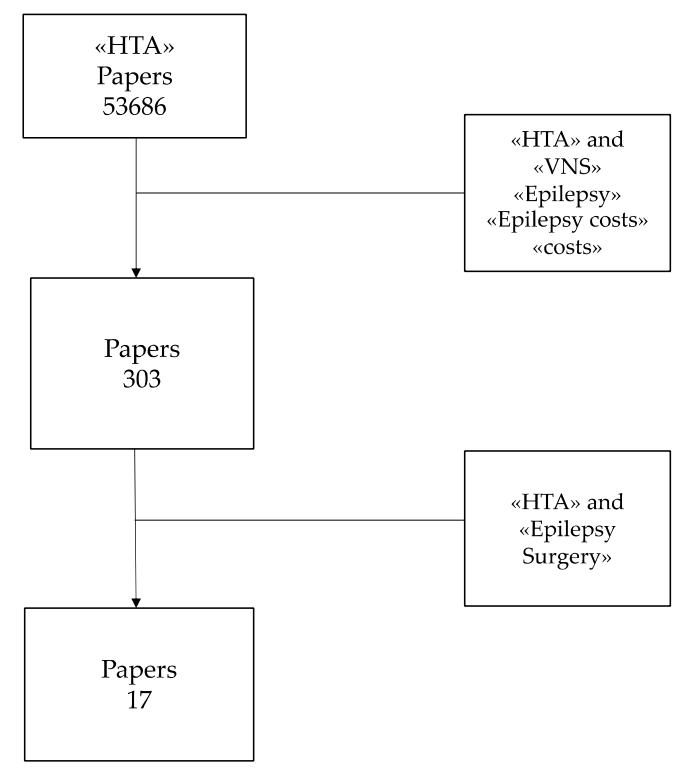

Figure 1. Literature search progression: (Health Technology Assessment: HTA).

By matching the term "VNS" with the issues of this HTA study ("social impact and costs", "eligibility and clinical results", "quality of life", "economic impact and productivity"), the number of papers decreased from 1939 to 95 because of some constrains including epilepsy, year of publication (from 2000) and studies including at least 10 cases (Figure 2).

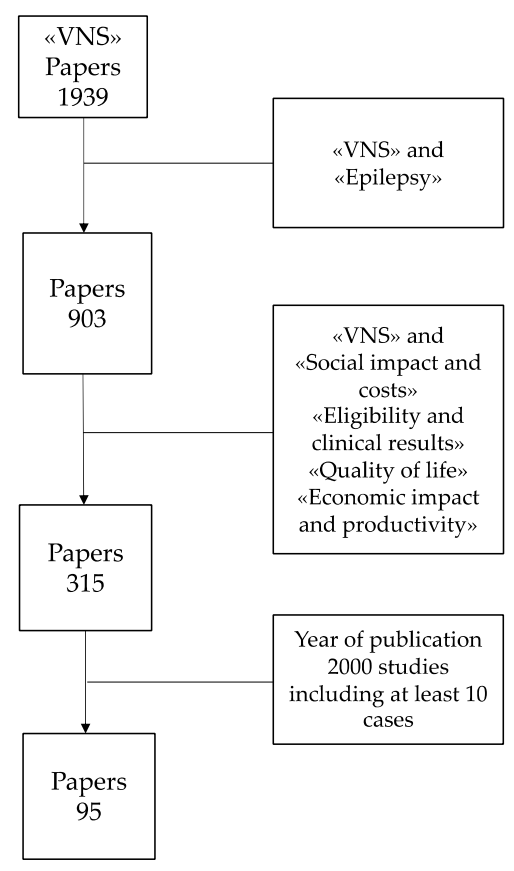

Figure 2. Literature search progression.

Analysis related to costs is crucial to the economic assessment, and it may turn out to be a useful tool to solve specific problems when choosing among available alternatives. The pillars of the present evaluation are cost (or opportunity cost) and benefit, i.e., the advantages or positive consequences of the action in question. Economic evaluation was performed considering the data of unit costs presented in "HTA Report on the management of drug-resistant epilepsies" of LICE (Lega Italiana Contro l'Epilessia) [28]. Data from three Italian hospitals in three different regions (Lazio, Emilia 
Romagna and Lombardia) were used to calculate the national average cost. The cost was calculated by averaging the unit price of the individual materials used for the treatment.

This HTA analysis focused mainly on the following issues: (a) social impact and costs of the disease; (b) clinical results after VNS therapy; (c) quality of life after VNS therapy; (d) economic impact and productivity regained after VNS; and (e) costs of VNS.

\section{Results and Discussion}

\subsection{Social Impact and Costs of the Disease}

The social burden, in terms of stigma and poor quality of life in patients of different ages, prognosis, comorbidity, and treatment response, has to be considered in the evaluation of the epilepsy's global burden [2]. In general, the concept of epilepsy as mental disorder is no longer accepted worldwide; however, epilepsy patients are often dealt with by society with stereotypical attitudes, such as fear or suspicion, as if they had psychological problems or mental retardation, or were considered to be unreliable in work activities due to seizures [29]. Epilepsy is a social issue even among the pediatric population - the Adolescent Mental Health Survey reported that approximately $25 \%$ of children aged 5-14 years had psychiatric difficulties with respect to 9\% of controls; children with epilepsy and psychiatric difficulties also had neurological comorbidities. Overall, children with epilepsy are growing with significant social problems that include less opportunities for future employment, lower chances of getting married, and possible difficulties in social relationships and in having an independent life [30,31]. A review with economic modeling has estimated the cost of epilepsy in 28 European countries. Despite a prevalence of 4.3 to 7.8 patients per 1000 persons, the total cost in Europe was estimated at EUR 15.5 billion, of which the indirect costs accounted for $55 \%$, the direct costs of health (particularly outpatient care which entailed an expenditure of EUR 1.3 billion) accounted for $18 \%$, and the non-medical cost for 27\% [32]; the cost per case treated/year ranged from EUR 2000 to 11,000. The economic burden of epilepsy is substantial, and it is inversely proportional to seizure control. Costs are higher in the first year after diagnosis than in the following years and vary according to the age of the subject $[33,34]$. The average cost per patient per year is higher for children than for adults and for newly diagnosed patients for whom the first diagnosis of epilepsy is addressed at the first visit. The major cost driver is hospitalization $(63.7 \%)$, followed by drugs $(10.5 \%)$, day-hospital visits $(4.1 \%)$, outpatient visits $(3.85 \%)$, other tests $(3.1 \%)$, and electroencephalograms $(2.3 \%)$ [35]. In particular, direct costs (outpatient and hospital) are based also on the age of onset of the disease, epilepsy features, frequency of seizures, and type of ASDs taken. Direct costs are higher for children and for the elderly over the age of 60, and they decrease during the second year of treatment. In addition, indirect costs (for example: lost productivity) account for about half of the total costs. Among the direct costs of healthcare, outpatient costs are prevalent in more stable patients, whereas hospital costs are prevalent in patients with higher frequency of seizures [23,36-39].

\subsection{VNS Eligibility and Clinical Results}

VNS has been used as an adjunctive treatment for drug-resistant epilepsy for more than 25 years and it seems to be effective in different types of epilepsy. VNS is a surgical procedure that may be indicated in drug-resistant patients excluded from resective surgery. The mechanism of action of this intermittent electrical stimulation of the vagus nerve is not completely understood [11]. The evaluation of the clinical result classifies a "responder" as a patient experiencing at least a $50 \%$ of seizures reduction $[40,41]$ (Table 1). In order to evaluate the efficacy and safety of VNS, the American Academy of Neurology (AAN) Guideline Development Subcommittee reviewed the full text of 216 articles published within 17 years. Just one article of the whole revision had an evidence level higher than class III [40]. The results collected had a level C of recommendation: (a) VNS as adjunctive treatment for children with partial or generalized epilepsy; (b) VNS potentially useful in patients with Lennox-Gastaut syndrome (LGS); (c) VNS progressively effective in patients over multiple years of 
exposure; and (d) VNS magnet activation associated with seizure abortion when used at the time of seizure auras [40]. Literature data from clinical trials on VNS established the following evidence: VNS reduces by at least $50 \%$ the frequency of seizures in $21-75 \%$ of subjects; the benefit of treatment might persist longer than 15 years of follow-up; and both adults and children could benefit from the treatment in $50-62 \%$ of patients $[16,17,19,23,42-49]$. On the other hand, a lower rate of responders is reported in other studies [15,50-58]. Among the huge bibliography reporting the outcome, numerous reviews remark not only the rate of seizure reduction but also the progression of the efficacy over years. Orosz et al. analyzed 347 children after VNS implantation. At 6, 12, and 24 months after implantation, $32.5 \%, 37.6 \%$, and $43.8 \%$, respectively, of patients had a $\geq 50 \%$ reduction in baseline seizure frequency of the predominant seizure type [59]. Favorable results were also evident for all secondary outcome measures, including changes in seizure duration, ictal and postictal severity, quality of life, clinical global impression of improvement, and safety [57]. The non-responders rate ranges between $25 \%$ and $65 \%$, and it could be useful to better define selection criteria for candidates to VNS. The VNS initial indication was restricted to drug-resistant patients, was not suitable for resective surgery, and was affected by partial epileptic seizures [17]. The Cochrane report concluded that VNS appears to be an effective and well-tolerated treatment for partial seizures; at the time of publication, however, VNSs were utilized in all ages and different kinds of epilepsies, syndromes and etiologies.

VNS is a neuromodulation approach that, among the palliative surgical therapies, is the most well-used worldwide. Since 1994, the first VNS study group concluded a safe and tolerable therapy for the implantation procedure, stimulating system and patient acceptance [13]. Kavcic et al. point out adverse events: hoarseness, increase salivation, cough, snoring, cervical muscle spasms and laryngeal pain. All effects, except for hoarseness during stimulation (serving as a marker of device function), were much milder or not present at the early follow-up visits [48]. Orosz et al. report complications related to surgery and to device malfunction ranging from 2 to $5 \%$, all reversible and in line with other literature data $[16,40,59,60]$.

Although more than 100,000 epileptic patients underwent VNS, the predictors of outcome are still under investigation, and the data reported are contradictory [43]. The efficacy of VNS on epilepsy at a younger age is still a matter of discussion [40,45,46,48,60-63]. Shorter history of epilepsy as a positive factor, reported by Kavcic, Wang and some other authors [48,64-66], is not accepted by all $[61,63,67]$. VNS appeared to have a role in malformation of cortical development, tuberous sclerosis, and post-traumatic and post-stroke epilepsies [46,68]. Localization-related epilepsies [69,70] and patients with interictal EEG focal activities have a better clinical outcome [68,71], but some authors report positive results in multifocal EEG patients as well as in generalized epilepsies [43,46,62,71-78]. Severe syndromes, such as Lennox-Gastaut and Dravet, show a high responder rate [20,79-81]. VNS has been used in very severe conditions including epilepsia partialis continua (EPC) and status epilepticus (SE). De Benedictis et.al report a series of four patients with SE who saw an improvement in seizure after 5 weeks since stimulation onset, and a persistence of the effect after a mean follow-up of 3 years [82]. On the other hand, a review of 17 papers did not recommend the use of VNS for resistant status epilepticus (RSE); nevertheless, a more recent review by Dibué-Adjei concludes that VNS can interrupt RSE in $74 \%$ of patients, with a class IV evidence level [83]. VNS was considered as a promising tool in the prevention or reduction in sudden unexpected death in epilepsy (SUDEP) [84-86]. However, the audit of 466 VNS cases enrolled at a single center showed that patients with VNS carried a similar risk for SUDEP as other drug refractory patients [87]. Tomson and Ryvlin suggested that the risk of SUDEP significantly decreases during long-term follow-up in VNS therapy [88,89]. 
Table 1. VNS series including a minimum 10 patients with a follow-up higher than 6 months.

\begin{tabular}{|c|c|c|c|c|c|}
\hline Author (Ref) & Patients Number & $\begin{array}{l}\text { Mean/Range Age at } \\
\text { Implantation }\end{array}$ & Mean/Range Follow-Up & Seizure Free \% $(n)$ & $\begin{array}{l}\text { Responders \% }(n) \text { of Patients } \\
\text { with } \geq 50 \% \text { Seizure Reduction }\end{array}$ \\
\hline Abubakr [15] & 31 & 14 to 62 years & 4 years & - & $53 \%(16)$ \\
\hline Gonzales [19] & 1194 & n.d. & 24-48 months & $8 \%$ & $63 \%$ \\
\hline Morris [40] & 481 & n.d. & $1-5$ years & n.d. & $55 \%$ \\
\hline Parain [42] & 10 & 5 to $20 \mathrm{y}$ & 22 months & $0 \%$ & $90 \%$ \\
\hline Janszky [43] & 47 & $22.7 \mathrm{y}$ & 22 months & $13 \%$ & n.d. \\
\hline Englot [46] & 3321 & n.d. & 3 to 64 months & n.d. & 21 to $50 \%$ \\
\hline Englot [47] & $\begin{array}{l}4483 \\
1104\end{array}$ & - & $\begin{array}{l}3 \text { months } \\
24 \text { months }\end{array}$ & - & $\begin{array}{l}44 \% \\
56 \%\end{array}$ \\
\hline Chrastina [49] & 74 & $18-59$ years & 10 years & n.d. & $63.6 \%$ \\
\hline Kuba [50] & 90 & 36.3 years & 5 years & (5) & $(44 / 85)$ \\
\hline Vonck [51] & 131 & 32 years & 33 months & $7 \%$ & $50 \%$ \\
\hline Patwardhan [54] & 38 & 11 months- 16 years & $\begin{array}{c}12 \text { moths } \\
\text { (10 months-18 months) }\end{array}$ & n.d. (n $29 \%>90 \%$ reduction) & $68 \%$ \\
\hline Nakken [55] & 47 & 34.4 years & 2.7 years & $2 \%(1 \mathrm{pt})$ & $32 \%(15)$ \\
\hline Fernandez [58] & 15 & 3 years $<$ & 4.3 years (1.4 years-10.2) & $0 \%$ & $\begin{array}{l}\text { categorical variable reported } \\
33 \% \text { "improvement" }\end{array}$ \\
\hline Terra [57] & 36 & up to 18 years & 12 months to 4 years & $(1 \mathrm{pt})$ & $55 \% \geq 50 \%$ seizure reduction \\
\hline Orosz [59] & 347 & 6 months to 17.9 years & 24 months & $8 \%(17 / 208)$ & $43.8 \%$ \\
\hline Kabir [60] & 69 & 10.69 years & 6 months to 10 years & $1.4 \%(1)$ & $\begin{array}{c}\text { 8.7\% (6) Engel II } \\
90 \% \text { (63) Engel III-IV }\end{array}$ \\
\hline Alexopoulos [61] & 46 & 12 years & 2 years & $10 \%(5)$ & $43.5 \%(20)$ \\
\hline
\end{tabular}


Table 1. Cont

\begin{tabular}{|c|c|c|c|c|c|}
\hline Author (Ref) & Patients Number & $\begin{array}{l}\text { Mean/Range Age at } \\
\text { Implantation }\end{array}$ & Mean/Range Follow-Up & Seizure Free \% (n) & $\begin{array}{l}\text { Responders \% ( } n \text { ) of Patients } \\
\text { with } \geq 50 \% \text { Seizure Reduction }\end{array}$ \\
\hline Colicchio [62] & 135 & 5 months to 64 years & 36 months & $5.1 \%$ & $49 \%$ \\
\hline Wang [66] & 1061 & $5-60$ years & 6 months -12 years & n.d. & $53.53 \%$ \\
\hline Ghaemi [68] & 144 & 3 to 65 years & 2 years & $(10)$ & $62 \%(89)$ \\
\hline Marras [69] & 35 & 6 to 52 years & 36 months & - & $51 \%(18)$ \\
\hline Amar [90] & $\begin{array}{c}921 \text { CS } \\
3822 \text { Non-CS }\end{array}$ & $\begin{array}{l}28 \text { years } \\
26 \text { years }\end{array}$ & $\begin{array}{l}24 \text { months } \\
24 \text { months }\end{array}$ & $\begin{array}{l}5 \% \\
8 \%\end{array}$ & $\begin{array}{l}55 \% \\
62 \%\end{array}$ \\
\hline Ulate-Campos [91] & 30 & 21 months (1-144) & 6-36 months & n.d. & $50 \%$ \\
\hline Moro de Faes [92] & 35 & $3-18$ years & 3 months to $2-3$ years & n.d. & $43 \%$ \\
\hline Soleman [93] & 45 & $133.9 \pm 184.5$ months & $72.3 \pm 39.8$ months & n.d. & $49.9 \%$ \\
\hline
\end{tabular}

Legend: underwent cranial surgery (CS) for epilepsy; not described (nd); patient (pt). 


\subsection{Quality of Life (QoL), Quality Adjusted Life Years (QALY) and Health-Related Quality of Life (HRQOL)} after VNS

The PuLsE (open prospective randomized long-term effectiveness) trial demonstrated that VNS therapy, adjunct to the best medical practice (BMP) in patients with drug-resistant focal seizures, was associated with a significant improvement in quality of life compared with BMP alone [94]. These data are widely confirmed by the literature $[18,90,91,94-99]$. The main findings after VNS therapy are the following: reduction in seizure frequency; improvement in verbal and figure recognition; increased experiences of attention and arousal; memory consolidation; cognitive flexibility and creativity; and decision-making [92,93,100-102]. However, changes are not significant or cover a limited number of domains only, especially in studies based on small samples [103]. The benefits are also quantified in terms of quality adjusted life years (QALYs), where the preference for a health state is quantified as a utility value, and then multiplied by years spent in the health state or years expected to live in a similar way $[104,105]$. QALY is an indicator that takes into account both the quality and the quantity of life lived. Helmers et al. study reports the QALY gained over lifetime after VNS implantation among pediatric patients. This study demonstrates that children gain about six QALYs and adolescents gain about 5 QALYs on average over the entire duration of life. The impact of VNS on QALY was assessed taking into account the following: the difference in the average utility score of QoL between the post-VNS period and the 6-months pre-VNS period; age; gender; and life expectancy in the entire VNS population [106]. VNS improved different health-related quality of life (HRQOL) domains - mainly cognitive, psychological, and social [92,107-109] — but it also improved memory, mood, behavior, alertness, achievement, and verbal skills [97,98,110-113].

\subsection{Economic Impact and Productivity Regained after VNS}

European Economic studies have shown that VNS treatment is beneficial from the perspective of third party payers and cost-effective from a societal perspective [114]. In a pilot study of 20 drug-resistant patients who were not candidates for surgical resection, VNS improved outcomes by reducing the direct cost of healthcare (drugs, outpatient consultations, hospitalizations, lab tests, device insertion, etc.) by about USD 3000 per year on average [115]. In fact, the total direct cost per patient pre- and post-implantation was approximately USD 6700 and UDS 3600, respectively [116]. A significant decrease in the direct cost of VNS-treated patients compared with conservatively treated patients was also reported by other groups [22,23,117-120].

Ben-Menachem et al. reported a saving in hospital costs by VNS equal to USD 3000 per patient per year by analyzing the direct costs of hospitalization in 43 drug-resistant patients in the 18 months preceding and 18 months following the implantation of the device [121]. The hospitalization costs were reduced both in VNS responders (reduction in seizures $>25 \%$ ) and in non-responders (reduction in seizures $<25 \%$ ). In the latter group, the intensive care unit (ICU) admissions were reduced from 6 to 0 with an average hospital stay from 24 to 0 days. In addition, emergency room admissions were reduced by $50 \%$ (from 8 to 4 ) and in-hospital admissions from 16 to 5 , with a reduction in days of hospitalization from 122 to 28 . Consequently, the costs of intensive care were cancelled, whereas those related to the emergency room and in-hospital stay significantly reduced.

The use of the VNS device has a positive effect on the consumption of healthcare resources and therefore on reducing the operating costs of the drug-resistant patients $[18,122,123]$. Data collected from 321 patients one year before to three years after VNS implantation showed a reduction higher than $70 \%$ of accidents and emergency unit attendance, as well as a decrease in severe injuries. The study also reported a decrease in elective (7\%) and non-elective (14\%) inpatient episodes [124]. Comparable results were collected in a larger group of patients [125]. Indeed, Helmers et al. showed that for patients with an age range of $1-11$ years $(n=238)$, hospitalizations and emergency room admissions were reduced post-VNS vs. pre-VNS (adjusted Internal Rate of Return (IRR) $=0.73$ and 0.74 , respectively). Average total healthcare costs were lower post-VNS vs. pre-VNS (USD 18,437 vs. USD18,839 quarterly). Additionally, for 12-17 years old patients $(n=207)$, hospitalizations and episodes of status epilepticus 
were reduced post-VNS vs. pre-VNS (adjusted IRR $=0.43$ and 0.25 , respectively). Average total healthcare costs were lower in the post-VNS vs. the pre-VNS period (USD 14,546 vs. USD19,695 quarterly) [106].

In a previous study, Helmers et al. demonstrated that resource use and epilepsy-related events gradually decreased after stimulator implantation [126]. As a matter of fact, VNS has a, low rate of complications and reoperations with a $2 \%$ incidence, and it is also associated with reduced seizure-related emergencies department visits and hospital admissions [125,127].

Finally an American study on VNS estimated the time spent on the management of the disease and consequently the time lost from work in 138 patients during the first year after VNS implantation [122]. The number of working days lost because of the disease reduced from 3.67 to 1.04 days, and the average time spent on the management of the disease decreased from 352.6 to $136.1 \mathrm{~min}$ per week. The economic value of the recovery of 2.63 days of average productivity per patient following implantation of VNS generates an economic return of EUR 275 per patient. This evaluation is the average of gross domestic product (GDP) per capita (resulting from the total yearly amount of USD 22,995 estimated by the International Monetary Fund, then divided by 220 working days).

\subsection{Costs of VNS}

Based on the calculations performed, the average total cost at the national level in Italy for the VNS implantation stage is EUR 26,543 (Table 2), and it includes the following: the cost of the VNS device, which is fixed and equal to EUR 21,084; the cost of surgery, which is EUR 3518 on average; and the cost of hospitalization, amounting on average to EUR 1941.

Table 2. Full cost hospital of VNS implantation-region details.

\begin{tabular}{ccccc}
\hline Items & Lazio & Emilia Romagna & Lombardia & National Average \\
\hline Surgery & EUR 3182 & EUR 5168 & EUR 2204 & EUR 3518 \\
VNS device & EUR 21,084 & EUR 21,084 & EUR 21,084 & EUR 21,084 \\
Hospital stay & EUR 1327 & EUR 2293 & EUR 2203 & EUR 1941 \\
Total costs & EUR 25,593 & EUR 28,545 & EUR 25,491 & EUR 26,543 \\
Total costs without device & EUR 4509 & EUR 7461 & EUR 4407 & EUR 5459 \\
\hline
\end{tabular}

Considering the cost of surgery, the variability among the different centers involved in the study derives from several factors (Table 3). Among these, the average duration of surgery, for example, ranging between one to three hours, accounts for the duration of the occupation of the operating room that could last between a minimum of 2 to a maximum of $5 \mathrm{~h}$, therefore resulting in an increase in the cost of the healthcare personnel employed during surgery. Finally, the variability of days of bed occupancy and the days of hospital stay have to be included.

Table 3. Consumption of health resources in VNS implantation stage.

\begin{tabular}{cccc}
\hline Health Resources & Min & Max & National Average \\
\hline Days of hospitalization/patient (no.) & 3 & 4 & 4 \\
Average duration of surgery (hours) & 1 & 3 & 2 \\
Duration occupancy operating room (hours) & 2 & 5 & 3 \\
Hours of intensive care/patient (no.) & 0 & 0 & 0 \\
\hline
\end{tabular}

In Table 4, the costs of each phase of VNS implantation are reported. For each phase the higher, lower, and average cost on the national level are considered.

By excluding the cost of the device and of preoperative tests from the calculation of the total cost of the VNS implantation stage, the surgery phase accounts for $64 \%$ of the average total cost, while the phase of hospitalization account for the remaining 36\%. However, the cost of the device accounted for $79 \%$ of the total cost, the cost of the surgery phase accounted for $13 \%$, and the cost of the hospitalization 
phase accounted for $7 \%$. Moreover, in good responder patients, after a period ranging between 5 and 7 years, a new internal pulse generator has to be replaced with additional costs of surgery and hospitalization, thus incurring a supplementary cost of EUR 16,000.

Table 4. Full average cost of VNS implantation stage.

\begin{tabular}{cccc}
\hline Items & Min (EUR) & Max (EUR) & National Average (EUR) \\
\hline Pre-operative diagnostic tests & 380 & 380 & 380 \\
Surgery & - & - & - \\
Materials & 38 & 80 & 65 \\
Personnel costs & 293 & 931 & 638 \\
Drugs & 189 & 199 & 193 \\
Operating room & 1684 & 3958 & 2622 \\
VNS device & 21,084 & 21,084 & 21,084 \\
Total cost of intervention & 23,288 & 26,252 & 24,602 \\
Inpatient & 2204 & 5168 & 3518 \\
Hospital stay & - & - & - \\
Inpatient drugs & 1067 & 1869 & 1572 \\
Personnel costs for inpatient & - & 5 & 3 \\
Other (e.g., perfusion) & 233 & 392 & 339 \\
Total cost of inpatient & 27 & 27 & 27 \\
Tof intervention without VNS device & 1327 & 2293 & 1941 \\
TOtal cost of VNS COST OF VNS IMPLANT & 24,615 & 28,545 & 26,543 \\
\end{tabular}

Regarding the remuneration of the Italian Health National System, the procedure of VNS implantation is classified in the category DRG 008 (operations on cranial and peripheral nerves and other intervention on the nervous system without complications).

Following the Italian Ministerial Decree published in 2006, a reimbursement of EUR 2770 per hospitalization is provided, and this amount was updated in 2012 to EUR 2326. However, the DRG financing does not cover, both on national and regional levels, the cost of the medical device which amounts to an average of EUR 21,000 (national price without VAT (value added tax) provided by the global medical technology company LivaNova. In order to cover the cost of the devices, in the last ten years, an additional reimbursement was provided in an increasing number of Italian regions. The reimbursement paid at present is insufficient even if the extra rate is added to the DRG 008 rate specifically for each region, amounting to EUR 15,000 for the Emilia Romagna and to EUR 13,312 for Lombardia. Currently, 9 out of 20 regions benefit from an extra payment. Although the reimbursement progressively improved for more $50 \%$ of the Italian population, an evident insufficient profitability of the DRG compared to the full cost of the implant device is still present.

\section{Conclusions}

In conclusion, our analysis indicates that VNS is a palliative treatment for reducing seizure frequency and intensity in drug-resistant epilepsy patients not eligible for resective surgery. Although large numbers of patients have been implanted worldwide, the amount of evidence on the eligibility criteria for VNS remains insufficient. Both responsive patients and their care-takers experience a subjective improvement in their quality of life. Despite its economic cost, VNS reduces care needs; therefore, its use may be justified in responder patients. There is an insufficient coverage of the DRG-based reimbursement compared to the full cost of the implant device.

Author Contributions: Conceptualization, C.E.M. and N.Z.; data curation, G.C., G.D.G., M.C. (Marilou Cavaliere), E.C., A.C. and F.V.; formal analysis, G.C. and A.C.; methodology, F.V.; project administration, G.D.G; software, G.C.; supervision, L.D.P., A.C., M.C. (Massimo Caulo), F.V. and N.Z.; validation, A.D.B., A.C., S.A., M.C. (Massimo Caulo), F.V. and N.Z.; Visualization, L.D.P. and A.D.B.; writing-review and editing, C.E.M., G.C. and M.C. (Marilou Cavaliere). All authors have read and agreed to the published version of the manuscript.

Funding: This research received no external funding This study was promoted by the Commission for Epilepsy Surgery of the Italian chapter (Lega Italiana Contro l'Epilessia, LICE) of the International League Against Epilepsy (ILAE). 
Acknowledgments: The study was carried out thanks to the methodological support and expertise of S. Lopatriello and P. Berto (BpE Consulting, Verona). We also thank M.P. Canevini, R. Guerrini R, G. Lo Russo G, R. Messina, G. Rubboli, M. Scerrati, R. Spreafico, G. Stola, V.Esposito, L. Tassi, P. Tinuper, M. Ritrovato and F. Lioi for their support in the realization of the study.

Conflicts of Interest: The authors declare no conflict of interest.

\section{Abbreviations}

$\begin{array}{ll}\text { AAN } & \text { American Academy of Neurology } \\ \text { ASDs } & \text { Antiseizure drugs } \\ \text { BMP } & \text { Best medical practice } \\ \text { DRG } & \text { Diagnosis-related group } \\ \text { EPC } & \text { Epilepsia Partialis Continua } \\ \text { FDA } & \text { Food \& Drug Administration } \\ \text { GDP } & \text { Gross Domestic Product } \\ \text { HTA } & \text { Health Technology Assessment } \\ \text { HRQOL } & \text { health-related quality of life } \\ \text { ICU } & \text { Intensive Care Unit } \\ \text { ILAE } & \text { International League Against Epilepsy } \\ \text { LGS } & \text { Lennox Gastaut Syndrome } \\ \text { LICE } & \text { Lega Italiana Contro l'Epilessia } \\ \text { NICE } & \text { National Institute for Clinical Excellence } \\ \text { QALY } & \text { Quality Adjusted Life Years; QoL: Quality of Life } \\ \text { RSE } & \text { Resistant Status Epilepticus; } \\ \text { SE } & \text { Status Epilepticus } \\ \text { SUDEP } & \text { Sudden Unexpected Death in Epilepsy } \\ \text { VAT } & \text { Value Added Tax } \\ \text { WHO } & \text { World Health Organization }\end{array}$

\section{References}

1. Ali, A. Global health: Epilepsy. Semin. Neurol. 2018, 38, 191-199. [CrossRef]

2. Pahl, K.; de Boer, H.M. Epilepsy and Rights. In Atlas: Epilepsy Care in the World; WHO: Geneva, Switzerland, 2005; pp. 72-73.

3. De Boer, H.M.; Mula, M.; Sander, J.W. The global burden and stigma of epilepsy. Epilepsy Behav. 2008, 12, 540-546. [CrossRef]

4. Tombini, M.; Assenza, G.; Quintiliani, L.; Ricci, L.; Lanzone, J.; De Mojà, R.; Ulivi, M.; Di Lazzaro, V. Epilepsy-associated stigma from the perspective of people with epilepsy and the community in Italy. Epilepsy Behav. 2019, 98, 66-72. [CrossRef]

5. Marras, C.E.; Canevini, M.P.; Colicchio, G.; Guerrini, R.; Rubboli, G.; Scerrati, M.; Spreafico, R.; Tassi, L.; Lorusso, G.; Tinuper, P.; et al. Health Technology Assessment report on the presurgical evaluation and surgical treatment of drug-resistant epilepsy. Epilepsia 2013, 54, 49-58. [CrossRef] [PubMed]

6. Wiebe, S.; Blume, W.T.; Girvin, J.P.; Eliasziw, M. A randomized, controlled trial of surgery for temporal-lobe epilepsy. N. Engl. J. Med. 2001, 345, 311-318. [CrossRef] [PubMed]

7. Mansouri, A.; Taslimi, S.; Abbasian, A.; Badhiwala, J.H.; Akbar, M.A.; Alotaibi, N.M.; Almenawer, S.A.; Weil, A.G.; Fallah, A.; Carmant, L.; et al. Surgical outcomes for medically intractable epilepsy in lowand middle-income countries: A systematic review and meta-analysis. J. Neurosurg. 2019, 131, 1068-1078. [CrossRef] [PubMed]

8. Téllez-Zenteno, J.F.; Dhar, R.; Wiebe, S. Long-term seizure outcomes following epilepsy surgery: A systematic review and meta-analysis. Brain 2005, 128, 1188-1198. [CrossRef] [PubMed]

9. Ryvlin, P.; Cross, J.H.; Rheims, S. Epilepsy surgery in children and adults. Lancet Neurol. 2014, 13, 1114-1126. [CrossRef]

10. Vagus Nerve Stimulation Study Group. A randomized controlled trial of chronic vagus nerve stimulation for treatment of medically intractable seizures. Neurology 1995, 45, 224-230. [CrossRef]

11. Schachter, S.C.; Saper, C.B. Vagus nerve stimulation. Epilepsia 1998, 39, 677-686. [CrossRef] 
12. Ben-Menachem, E.; Manon-Espaillat, R.; Ristanovic, R.; Wilder, B.J.; Stefan, H.; Mirza, W.; Tarver, W.B.; Wernicke, J.F.; First International Vagus Nerve Stimulation Study Group. Vagus Nerve Stimulation for Treatment of Partial Seizures: 1. A controlled study of effect on seizures. Epilepsia 1994, 35, 616-626. [CrossRef] [PubMed]

13. Ramsay, R.E.; Uthman, B.M.; Augustinsson, L.E.; Upton, A.R.M.; Naritoku, D.; Willis, J.; Treig, T.; Barolat, G.; Wernicke, J.F.; First International Vagus Nerve Stimulation Study Group. Vagus Nerve Stimulation for Treatment of Partial Seizures: 2. Safety, Side Effects, and Tolerability. Epilepsia 1994, 35, 627-636. [CrossRef] [PubMed]

14. Murphy, J.V.; Torkelson, R.; Dowler, I.; Simon, S.; Hudson, S. Vagal Nerve Stimulation in Refractory Epilepsy. Arch. Pediatr. Adolesc. Med. 2003, 157, 560-564. [CrossRef] [PubMed]

15. Abubakr, A.; Wambacq, I. Long-term outcome of vagus nerve stimulation therapy in patients with refractory epilepsy. J. Clin. Neurosci. 2008, 15, 127-129. [CrossRef] [PubMed]

16. Panebianco, M.; Zavanone, C.; Dupont, S.; Restivo, D.; Pavone, A. Vagus nerve stimulation therapy in partial epilepsy: A review. Acta Neurol. Belg. 2016, 116, 241-248. [CrossRef]

17. Panebianco, M.; Rigby, A.; Weston, J.; Marson, A.G. Vagus nerve stimulation for partial seizures. Cochrane Database Syst. Rev. 2015, 2015, CD002896. [CrossRef]

18. Wheless, J.W.; Gienapp, A.J.; Ryvlin, P. Vagus nerve stimulation (VNS) therapy update. Epilepsy Behav. 2018, 88, 2-10. [CrossRef]

19. González, H.; Yengo-Kahn, A.M.; Englot, D.J. Vagus Nerve Stimulation for the Treatment of Epilepsy. Neurosurg. Clin. N. Am. 2019, 30, 219-230. [CrossRef]

20. Fan, J.; Shan, W.; Wu, J.; Wang, Q. Research progress of vagus nerve stimulation in the treatment of epilepsy. CNS Neurosci. Ther. 2019, 25, 1222-1228. [CrossRef]

21. Shahwan, A.; Bailey, C.; Maxiner, W.; Harvey, A.S. Vagus nerve stimulation for refractory epilepsy in children: More to VNS than seizure frequency reduction. Epilepsia 2009, 50, 1220-1228. [CrossRef]

22. Kopciuch, D.; Barciszewska, A.-M.; Fliciński, J.; Zaprutko, T.; Kus, K.; Steinborn, B.; Nowakowska, E. Analysis of pharmacotherapy regimen and costs in patients with drug-resistant epilepsy following vagus nerve stimulation therapy: A single-center study (Poland). Acta Neurol. Belg. 2019, 120, 115-122. [CrossRef] [PubMed]

23. Kopciuch, D.; Barciszewska, A.-M.; Fliciński, J.; Paczkowska, A.; Winczewska-Wiktor, A.; Jankowski, R.; Steinborn, B.; Nowakowska, E. Economic and clinical evaluation of vagus nerve stimulation therapy. Acta Neurol. Scand. 2019, 140, 244-251. [CrossRef] [PubMed]

24. Cukiert, A. Vagus Nerve Stimulation for Epilepsy: An Evidence-Based Approach. Prog. Neurol. Surg. 2015, 29, 39-52. [PubMed]

25. Cicchetti, A.P. Presente e Futuro dell'Health Technology Assessment. Care 2009, 2, 21-23.

26. Fattore, G.; Cavallo, M.C.; Tarricone, R. Lo sviluppo del Health Technology Assessment in Italia: Contenuti, approcci e riferimenti internazionali. Rapporto OASI 2008, 4, 151-178.

27. Goodman, C.S. HTA 101: Introduction to Health Technology Assessment; Bethesda, M.D., Ed.; National Library of Medicine: Bethesda, MD, USA, 2014. Available online: https://www.nlm.nih.gov/nichsr/hta101/HTA_101_ FINAL_7-23-14.pdf (accessed on 1 July 2020).

28. Lopatriello, S.; Berto, P.; Canevini, M.B.; Colicchio, G.; Rubboli, G.; Spreafico, R.; Tassi, L.; Tinuper, P. La Gestione Delle Epilessie Farmacoresistenti. Hta Report. LICE. 2010. Available online: http://www.lice.it/pdf/ report_HTA_old.pdf (accessed on 1 July 2020).

29. Jacoby, A.; Austin, J.K. Social stigma for adults and children with epilepsy. Epilepsia 2007, 48, 6-9. [CrossRef]

30. Camfield, C.S.; Camfield, P.R. Long-term social outcomes for children with epilepsy. Epilepsia 2007, 48, 3-5. [CrossRef]

31. Bajaj, J.; Tripathi, M.; Dwivedi, R.; Sapra, S.; Gulati, S.; Garg, A.; Tripathi, M.; Bal, C.S.; Chandra, S.P. Does surgery help in reducing stigma associated with drug refractory epilepsy in children? Epilepsy Behav. 2018, 80, 197-201. [CrossRef]

32. Pugliatti, M.; Beghi, E.; Forsgren, L.; Ekman, M.; Sobocki, P. Estimating the Cost of Epilepsy in Europe: A Review with Economic Modeling. Epilepsia 2007, 48, 2224-2233. [CrossRef]

33. Argumosa, A.; Herranz, J.L. Childhood epilepsy: A critical review of cost-of-illness studies. Epileptic Disord. 2004, 6, 31-40. 
34. Wijnen, B.; Schat, S.L.; De Kinderen, R.J.; Colon, A.; Ossenblok, P.P.; Evers, S.M.A.A. Burden of disease of people with epilepsy during an optimized diagnostic trajectory: Costs and quality of life. Epilepsy Res. 2018, 146, 87-93. [CrossRef] [PubMed]

35. Berto, P.; Tinuper, P.; Viaggi, S. Cost-of-Illness of Epilepsy in Italy. PharmacoEconomics 2000, 17, $197-208$. [CrossRef] [PubMed]

36. Ekman, M.; Forsgren, L. Economic evidence in epilepsy: A review. Eur. J. Health Econ. 2004, 5, s36-s42. [CrossRef]

37. De Kinderen, R.J.; Postulart, D.; Aldenkamp, A.P.; Evers, S.M.A.A.; Lambrechts, D.A.; De Louw, A.; Majoie, M.; Grutters, J.P. Cost-effectiveness of the ketogenic diet and vagus nerve stimulation for the treatment of children with intractable epilepsy. Epilepsy Res. 2015, 110, 119-131. [CrossRef]

38. Kim, H.J.; Kim, H.D.; Lee, J.S.; Heo, K.; Kim, D.S.; Kang, H.-C. Long-term prognosis of patients with Lennox-Gastaut syndrome in recent decades. Epilepsy Res. 2015, 110, 10-19. [CrossRef]

39. Healy, S.; Lang, J.; Naude, J.T.W.; Gibbon, F.; Leach, P. Vagal nerve stimulation in children under 12 years old with medically intractable epilepsy. Childs Nerv. Syst. 2013, 29, 2095-2099. [CrossRef]

40. Morris, G.L.; Gloss, D.; Buchhalter, J.; Mack, K.J.; Nickels, K.; Harden, C. Evidence-based guideline update: Vagus nerve stimulation for the treatment of epilepsy: Report of the Guideline Development Subcommittee of the American Academy of Neurology. Neurology 2013, 81, 1453-1459. [CrossRef] [PubMed]

41. McHugh, J.C.; Singh, H.W.; Phillips, J.; Murphy, K.; Doherty, C.P.; Delanty, N. Outcome Measurement after Vagal Nerve Stimulation Therapy: Proposal of a New Classification. Epilepsia 2007, 48, 375-378. [CrossRef] [PubMed]

42. Parain, D.; Penniello, M.J.; Berquen, P.; Delangre, T.; Billard, C.; Murphy, J.V. Vagal nerve stimulation in tuberous sclerosis complex patients. Pediatr. Neurol. 2001, 25, 213-216. [CrossRef]

43. Janszky, J.; Hoppe, M.; Behne, F.; Tuxhorn, I.; Pannek, H.W.; Ebner, A. Vagus nerve stimulation: Predictors of seizure freedom. J. Neurol. Neurosurg. Psychiatry 2005, 76, 384-389. [CrossRef] [PubMed]

44. Terra-Bustamante, V.C.; Machado, H.R.; Oliveira, R.D.S.; Serafini, L.N.; Souza-Oliveira, C.; Escorsi-Rosset, S.; Yacubian, E.M.T.; Naffah-Mazzacoratti, M.; Scorza, C.A.; A Cavalheiro, E.; et al. Rasmussen encephalitis: Long-term outcome after surgery. Child's Nerv. Syst. 2009, 25, 583-589. [CrossRef] [PubMed]

45. Klinkenberg, S.; Aalbers, M.; Vles, J.S.H.; Cornips, E.; Rijkers, K.; Leenen, L.; Kessels, F.G.H.; Aldenkamp, A.P.; Majoie, M. Vagus nerve stimulation in children with intractable epilepsy: A randomized controlled trial. Dev. Med. Child Neurol. 2012, 54, 855-861. [CrossRef] [PubMed]

46. Englot, D.J.; Chang, E.F.; Auguste, K.I. Vagus nerve stimulation for epilepsy: A meta-analysis of efficacy and predictors of response. J. Neurosurg. 2011, 115, 1248-1255. [CrossRef] [PubMed]

47. Englot, D.J.; Chang, E.F.; Auguste, K.I. Efficacy of Vagus Nerve Stimulation for Epilepsy by Patient Age, Epilepsy Duration, and Seizure Type. Neurosurg. Clin. N. Am. 2011, 22, 443-448. [CrossRef] [PubMed]

48. Kavčič, A.; Kajdič, N.; Primec, Z.R.; Krajnc, N.; Žgur, T. Efficacy and tolerability of vagus nerve stimulation therapy (VNS) in Slovenian epilepsy patients: Younger age and shorter duration of epilepsy might result in better outcome. Acta Clin. Croat. 2019, 58, 255-264. [CrossRef]

49. Chrastina, J.; Novák, Z.; Zeman, T.; Kocvarova, J.; Pail, M.; Doležalová, I.; Jarkovsky, J.; Brázdil, M. Single-center long-term results of vagus nerve stimulation for epilepsy: A 10-17 year follow-up study. Seizure 2018, 59, 41-47. [CrossRef]

50. Kuba, R.; Brázdil, M.; Kalina, M.; Procházka, T.; Hovorka, J.; Nežádal, T.; Hadac, J.; Brožová, K.; Sebroňová, V.; Komarek, V.; et al. Vagus nerve stimulation: Longitudinal follow-up of patients treated for 5 years. Seizure 2009, 18, 269-274. [CrossRef]

51. Vonck, K.; Thadani, V.; Gilbert, K.; Dedeurwaerdere, S.; De Groote, L.; De Herdt, V.; Goossens, L.; Gossiaux, F.; Achten, E.; Thiery, E.; et al. Vagus nerve stimulation for refractory epilepsy: A transatlantic experience. J. Clin. Neurophysiol. 2004, 21, 283-289. [CrossRef]

52. De Herdt, V.; Boon, P.; Ceulemans, B.; Hauman, H.; Lagae, L.; Legros, B.; Sadzot, B.; Van Bogaert, P.; Van Rijckevorsel, K.; Verhelst, H.; et al. Vagus nerve stimulation for refractory epilepsy: A Belgian multicenter study. Eur. J. Paediatr. Neurol. 2007, 11, 261-269. [CrossRef]

53. Rossignol, E.; Lortie, A.; Thomas, T.; Bouthiller, A.; Scavarda, D.; Mercier, C.; Carmant, L. Vagus nerve stimulation in pediatric epileptic syndromes. Seizure 2009, 18, 34-37. [CrossRef]

54. Patwardhan, R.V.; Stong, B.; Bebin, E.M.; Mathisen, J.; A Grabb, P. Efficacy of vagal nerve stimulation in children with medically refractory epilepsy. Neurosurgery 2000, 47, 1353-1358. [CrossRef] [PubMed] 
55. Nakken, K.O.; Henriksen, O.; Røste, G.K.; Lossius, R. Vagal nerve stimulation-The Norwegian experience. Seizure 2003, 12, 37-41. [CrossRef] [PubMed]

56. Ardesch, J.; Buschman, H.; Wagener-Schimmel, L.; Van Der Aa, H.; Hageman, G. Vagus nerve stimulation for medically refractory epilepsy: A long-term follow-up study. Seizure 2007, 16, 579-585. [CrossRef] [PubMed]

57. Terra, V.C.; Furlanetti, L.L.; Nunes, A.A.; Thome, U.; Nisyiama, M.A.; Sakamoto, A.C.; Machado, H.R. Vagus nerve stimulation in pediatric patients: Is it really worthwhile? Epilepsy Behav. 2014, 31, 329-333. [CrossRef]

58. Fernandez, L.; Gedela, S.; Tamber, M.; Sogawa, Y. Vagus nerve stimulation in children less than 3 years with medically intractable epilepsy. Epilepsy Res. 2015, 112, 37-42. [CrossRef] [PubMed]

59. Orosz, I.; McCormick, D.; Zamponi, N.; Varadkar, S.; Feucht, M.; Parain, D.; Griens, R.; Vallée, L.; Boon, P.; Rittey, C.; et al. Vagus nerve stimulation for drug-resistant epilepsy: A European long-term study up to 24 months in 347 children. Epilepsia 2014, 55, 1576-1584. [CrossRef]

60. Kabir, S.M.R.; Rajaraman, C.; Rittey, C.; Zaki, H.S.; Kemeny, A.A.; McMullan, J. Vagus nerve stimulation in children with intractable epilepsy: Indications, complications and outcome. Childs Nerv. Syst. 2009, 25, 1097-1100. [CrossRef]

61. Alexopoulos, A.V.; Kotagal, P.; Loddenkemper, T.; Hammel, J.; Bingaman, W.E. Long-term results with vagus nerve stimulation in children with pharmacoresistant epilepsy. Seizure 2006, 15, 491-503. [CrossRef]

62. Colicchio, G.; Policicchio, D.; Barbati, G.; Cesaroni, E.; Fuggetta, F.; Meglio, M.; Papacci, F.; Rychlicki, F.; Scerrati, M.; Zamponi, N. Vagal nerve stimulation for drug-resistant epilepsies in different age, aetiology and duration. Childs Nerv. Syst. 2010, 26, 811-819. [CrossRef]

63. Kocvarova, J.; Novák, Z.; Doležalová, I.; Svoboda, M.; Brázdil, M.; Chrastina, J. Older Age and Longer Epilepsy Duration Do Not Predict Worse Seizure Reduction Outcome after Vagus Nerve Stimulation. J. Neurol. Surg. Part A Central Eur. Neurosurg. 2017, 79, 152-158. [CrossRef]

64. Renfroe, J.B.; Wheless, J.W. Earlier use of adjunctive vagus nerve stimulation therapy for refractory epilepsy. Neurology 2002, 59. [CrossRef] [PubMed]

65. LaBar, D. Vagus nerve stimulation for 1 year in 269 patients on unchanged antiepileptic drugs. Seizure 2004, 13, 392-398. [CrossRef] [PubMed]

66. Wang, H.-J.; Tan, G.; Zhu, L.-N.; Chen, D.; Xu, D.; Chu, S.-S.; Liu, L. Predictors of seizure reduction outcome after vagus nerve stimulation in drug-resistant epilepsy. Seizure 2019, 66, 53-60. [CrossRef] [PubMed]

67. Helmers, S.L.; Griesemer, D.A.; Dean, J.C.; Sanchez, J.D.; LaBar, D.; Murphy, J.V.; Bettis, D.; Park, Y.D.; Shuman, R.M.; Morris, G.L. Observations on the Use of Vagus Nerve Stimulation Earlier in the Course of Pharmacoresistant Epilepsy: Patients With Seizures for Six Years or Less. Neurology 2003, 9, 160-164. [CrossRef]

68. Ghaemi, K.; Elsharkawy, A.E.; Schulz, R.; Hoppe, M.; Polster, T.; Pannek, H.; Ebner, A. Vagus nerve stimulation: Outcome and predictors of seizure freedom in long-term follow-up. Seizure 2010, 19, 264-268. [CrossRef]

69. Marras, C.E.; Chiesa, V.; De Benedictis, A.; Franzini, A.; Rizzi, M.; Villani, F.; Ragona, F.; Tassi, L.; Vignoli, A.; Freri, E.; et al. Vagus nerve stimulation in refractory epilepsy: New indications and outcome assessment. Epilepsy Behav. 2013, 28, 374-378. [CrossRef]

70. Casazza, M.; Avanzini, G.; Ferroli, P.; Villani, F.; Raggi, A. Vagal nerve stimulation: Relationship between outcome and electroclinical seizure pattern. Seizure 2006, 15, 198-207. [CrossRef]

71. Alsaadi, T.M.; Laxer, K.D.; Barbaro, N.M.; Marks, W.J.; Garcia, P.A. Vagus nerve stimulation for the treatment of bilateral independent temporal lobe epilepsy. Epilepsia 2001, 42, 954-956. [CrossRef]

72. Kuba, R.; Brázdil, M.; Novák, Z.; Chrastina, J.; Rektor, I. Effect of vagal nerve stimulation on patients with bitemporal epilepsy. Eur. J. Neurol. 2003, 10,91-94. [CrossRef]

73. Hilderink, J.; Tjepkema-Cloostermans, M.C.; Geertsema, A.; Glastra-Zwiers, J.; De Vos, C.C. Predicting success of vagus nerve stimulation (VNS) from EEG symmetry. Seizure 2017, 48, 69-73. [CrossRef]

74. De Vos, C.; Melching, L.; Van Schoonhoven, J.; Ardesch, J.; De Weerd, A.; Van Lambalgen, H.; Van Putten, M.J. Predicting success of vagus nerve stimulation (VNS) from interictal EEG. Seizure 2011, 20, 541-545. [CrossRef] [PubMed]

75. Rolston, J.D.; Englot, D.J.; Wang, R.D.; Garcia, P.A.; Chang, E.F. Corpus callosotomy versus vagus nerve stimulation for atonic seizures and drop attacks: A systematic review. Epilepsy Behav. 2015, 51, 13-17. [CrossRef] [PubMed] 
76. Cukiert, A.; Cukiert, C.M.; Burattini, J.A.; Lima, A.M.; Forster, C.R.; Baise, C.; Argentoni-Baldochi, M. Long-term outcome after callosotomy or vagus nerve stimulation in consecutive prospective cohorts of children with Lennox-Gastaut or Lennox-like syndrome and non-specific MRI findings. Seizure 2013, 22, 396-400. [CrossRef] [PubMed]

77. Guillamón, E.; Miró, J.; Gutiérrez, A.; Conde, R.; Falip, M.; Jaraba, S.; Plans, G.; Garcés, M.; Villanueva, V. Combination of Corpus Callosotomy and Vagus Nerve Stimulation in the Treatment of Refractory Epilepsy. Eur. Neurol. 2013, 71, 65-74. [CrossRef] [PubMed]

78. Kossoff, E.H.; Shields, W.D. Nonpharmacologic care for patients with Lennox-Gastaut syndrome: Ketogenic diets and vagus nerve stimulation. Epilepsia 2014, 55, 29-33. [CrossRef]

79. Ben-Menachem, E.; Hellström, K.; Waldton, C.; Augustinsson, L.E. Evaluation of refractory epilepsy treated with vagus nerve stimulation for up to 5 years. Neurology 1999, 52, 1265. [CrossRef]

80. Frost, M.; Gates, J.; Helmers, S.L.; Wheless, J.W.; Levisohn, P.; Tardo, C.; Conry, J.A. Vagus nerve stimulation in children with refractory seizures associated with Lennox-Gastaut syndrome. Epilepsia 2001, 42, 1148-1152. [CrossRef]

81. Lundgren, J.; Amark, P.; Blennow, G.; Stromblad, L.G.; Wallstedt, L. Vagus nerve stimulation in 16 children with refractory epilepsy. Epilepsia 1998, 39, 809-813. [CrossRef]

82. De Benedictis, A.; Freri, E.; Rizzi, M.; Franzini, A.; Ragona, F.; Specchio, N.; Rebessi, E.; Casazza, M.; Granata, T.; Marras, C.E. Vagus nerve stimulation for drug-resistant Epilepsia Partialis Continua: Report of four cases. Epilepsy Res. 2013, 107, 163-171. [CrossRef]

83. Dibué-Adjei, M.; Brigo, F.; Yamamoto, T.; Vonck, K.; Trinka, E. Vagus nerve stimulation in refractory and super-refractory status epilepticus-A systematic review. Brain Stimul. 2019, 12, 1101-1110. [CrossRef]

84. Annegers, J.F.; Coan, S.P.; Hauser, W.A.; Leestma, J. Epilepsy, vagal nerve stimulation by the NCP system, all-cause mortality, and sudden, unexpected, unexplained death. Epilepsia 2000, 41, 549-553. [CrossRef] [PubMed]

85. Kotagal, P. Neurostimulation: Vagus Nerve Stimulation and Beyond. Semin. Pediatr. Neurol. 2011, 18, 186-194. [CrossRef] [PubMed]

86. Terra, V.C.; Nisyiama, M.A.; Abrão, J.; Sakamoto, A.C.; Machado, H.R.; Arida, R.M.; A Cavalheiro, E.; Scorza, F.A. Epileptologists probe vagus nerve stimulation in children with refractory epilepsy: A promise against sudden unexpected death in epilepsy. Arq. Neuro-Psiquiatria 2012, 70, 953-955. [CrossRef] [PubMed]

87. Granbichler, C.A.; Nashef, L.; Selway, R.; E Polkey, C. Mortality and SUDEP in epilepsy patients treated with vagus nerve stimulation. Epilepsia 2015, 56, 291-296. [CrossRef] [PubMed]

88. Tomson, T.; Sveinsson, O.; Carlsson, S.; Andersson, T. Evolution over time of SUDEP incidence: A nationwide population-based cohort study. Epilepsia 2018, 59, e120-e124. [CrossRef]

89. Ryvlin, P.; So, E.; Gordon, C.M.; Hesdorffer, D.C.; Sperling, M.R.; Devinsky, O.; Bunker, M.T.; Olin, B.; Friedman, D. Long-term surveillance of SUDEP in drug-resistant epilepsy patients treated with VNS therapy. Epilepsia 2018, 59, 562-572. [CrossRef]

90. Amar, A.P.; Apuzzo, M.L.; Liu, C.Y. Vagus Nerve Stimulation Therapy After Failed Cranial Surgery for Intractable Epilepsy. Neurosurgery 2008, 62, 1086-1093. [CrossRef]

91. Ulate-Campos, A.; Cean-Cabrera, L.; Petanas-Argemi, J.; Garcia-Fructuoso, G.; Aparicio, J.; López-Sala, A.; Palacio-Navarro, A.; Mas, M.; Muchart, J.; Rebollo, M.; et al. Resultados de la colocación del estimulador del nervio vago en epilepsia y calidad de vida en un hospital pediátrico. Neurología 2015, 30, 465-471. [CrossRef]

92. De Faes, G.M.; Moyano, B.S.; Extremera, V.C.; Vinués, B.M.; Fernández, M.G.; Jiménez, M.; Ángeles, P.; Martín, M.B.R.; Ezquiaga, J.G.; Rodríguez, A.D.; et al. Diez años de experiencia con el estimulador del nervio vago en una población pediátrica. Rev. Neurol. 2018, 67, 382. [CrossRef]

93. Soleman, J.; Stein, M.; Knorr, C.; Datta, A.N.; Constantini, S.; Fried, I.; Guzman, R.; Kramer, U. Improved quality of life and cognition after early vagal nerve stimulator implantation in children. Epilepsy Behav. 2018, 88, 139-145. [CrossRef]

94. Ryvlin, P.; Gilliam, F.G.; Nguyen, D.K.; Colicchio, G.; Iudice, A.; Tinuper, P.; Zamponi, N.; Aguglia, U.; Wagner, L.; Minotti, L.; et al. The long-term effect of vagus nerve stimulation on quality of life in patients with pharmacoresistant focal epilepsy: The PuLsE (Open Prospective Randomized Long-term Effectiveness) trial. Epilepsia 2014, 55, 893-900. [CrossRef] [PubMed]

95. Majoie, M.; Berfelo, M.; Aldenkamp, A.; Renier, W.; Kessels, A. Vagus nerve stimulation in patients with catastrophic childhood epilepsy, a 2-year follow-up study. Seizure 2005, 14, 10-18. [CrossRef] [PubMed] 
96. Mikati, M.A.; Ataya, N.F.; El-Ferezli, J.C.; Baghdadi, T.S.; Turkmani, A.H.; Comair, Y.G.; Kansagra, S.; Najjar, M.W. Quality of life after vagal nerve stimulator insertion. Epileptic Disord. 2009, 11, 067-074. [CrossRef] [PubMed]

97. Ekmekçi, H.; Kaptan, H. Vagal nerve stimulation has robust effects on neuropsychiatric assessment in resistant epilepsy: A clinical series with clinical experiences. Turk. Neurosurg. 2018, 29, 213-221. [CrossRef] [PubMed]

98. Englot, D.J.; Hassnain, K.H.; Rolston, J.D.; Harward, S.C.; Sinha, S.R.; Haglund, M.M. Quality-of-life metrics with vagus nerve stimulation for epilepsy from provider survey data. Epilepsy Behav. 2016, 66, 4-9. [CrossRef]

99. Tsai, J.-D.; Chang, Y.-C.; Lin, L.-C.; Hung, K.-L. The neuropsychological outcome of pediatric patients with refractory epilepsy treated with VNS-A 24-month follow-up in Taiwan. Epilepsy Behav. 2016, 56, 95-98. [CrossRef]

100. Vonck, K.; Raedt, R.; Naulaerts, J.; De Vogelaere, F.; Thiery, E.; Van Roost, D.; Aldenkamp, A.P.; Miatton, M.; Boon, P. Vagus nerve stimulation, 25 years later! What do we know about the effects on cognition? Neurosci. Biobehav. Rev. 2014, 45, 63-71. [CrossRef]

101. Sourbron, J.; Klinkenberg, S.; Kessels, A.; Schelhaas, H.J.; Lagae, L.; Majoie, M. Vagus Nerve Stimulation in children: A focus on intellectual disability. Eur. J. Paediatr. Neurol. 2017, 21, 427-440. [CrossRef]

102. Schevernels, H.; Van Bochove, M.E.; De Taeye, L.; Bombeke, K.; Vonck, K.; Van Roost, D.; De Herdt, V.; Santens, P.; Raedt, R.; Boehler, C.N. The effect of vagus nerve stimulation on response inhibition. Epilepsy Behav. 2016, 64, 171-179. [CrossRef]

103. DeGiorgio, C.M.; Schachter, S.C.; Handforth, A.; Salinsky, M.; Thompson, J.; Uthman, B.; Reed, R.; Collin, S.; Tecoma, E.; Morris, G.L.; et al. Prospective Long-Term Study of Vagus Nerve Stimulation for the Treatment of Refractory Seizures. Epilepsia 2000, 41, 1195-1200. [CrossRef]

104. Aburahma, S.K.; Alzoubi, F.Q.; Hammouri, H.; Masri, A. Vagus nerve stimulation therapy in a developing country: A long term follow up study and cost utility analysis. Seizure 2015, 25, 167-172. [CrossRef] [PubMed]

105. Soleman, J.; Knorr, C.; Datta, A.N.; Strozzi, S.; Ramelli, G.P.; Mariani, L.; Guzman, R. Early vagal nerve stimulator implantation in children: Personal experience and review of the literature. Childs Nerv. Syst. 2017, 34, 893-900. [CrossRef]

106. Helmers, S.L.; Duh, M.S.; Guérin, A.; Sarda, S.P.; Samuelson, T.M.; Bunker, M.T.; Olin, B.; Jackson, S.D.; Faught, E. Clinical outcomes, quality of life, and costs associated with implantation of vagus nerve stimulation therapy in pediatric patients with drug-resistant epilepsy. Eur. J. Paediatr. Neurol. 2012, 16, 449-458. [CrossRef] [PubMed]

107. Sherman, E.M.S.; Connolly, M.; Slick, D.J.; Eyrl, K.L.; Steinbok, P.; Farrell, K. Quality of Life and Seizure Outcome After Vagus Nerve Stimulation in Children With Intractable Epilepsy. J. Child Neurol. 2008, 23, 991-998. [CrossRef] [PubMed]

108. Li, S.-T.; Chiu, N.-C.; Kuo, Y.-T.; Shen, E.-Y.; Tsai, P.-C.; Ho, C.-S.; Wu, W.-H.; Chen, J.-C.; Wang, C.-Y.; Wang, H.-S.; et al. Parenting stress in parents of children with refractory epilepsy before and after vagus nerve stimulation implantation. Pediatr. Neonatol. 2017, 58, 516-522. [CrossRef] [PubMed]

109. Amin, S.; Majumdar, A.; Mallick, A.; Patel, J.; Scatchard, R.; Partridge, C.; Lux, A. Caregiver's perception of epilepsy treatment, quality of life and comorbidities in an international cohort of CDKL5 patients. Hippokratia 2017, 21, 130-135.

110. You, S.J.; Kang, H.-C.; Kim, H.D.; Ko, T.-S.; Kim, D.-S.; Hwang, Y.S.; Kim, D.S.; Lee, J.-K.; Park, S.K. Vagus Nerve Stimulation in Intractable Childhood Epilepsy: A Korean Multicenter Experience. J. Korean Med. Sci. 2007, 22, 442-445. [CrossRef]

111. Spindler, P.; Bohlmann, K.; Straub, H.-B.; Vajkoczy, P.; Schneider, U.C. Effects of vagus nerve stimulation on symptoms of depression in patients with difficult-to-treat epilepsy. Seizure 2019, 69, 77-79. [CrossRef]

112. Chan, A.Y.; Rolston, J.D.; Rao, V.R.; Chang, E.F. Effect of neurostimulation on cognition and mood in refractory epilepsy. Epilepsia Open 2018, 3, 18-29. [CrossRef]

113. Sun, L.; Peräkylä, J.; Holm, K.; Haapasalo, J.; Lehtimäki, K.; Ogawa, K.H.; Peltola, J.; Hartikainen, K.M. Vagus nerve stimulation improves working memory performance. J. Clin. Exp. Neuropsychol. 2017, 39, 954-964. [CrossRef]

114. Health Care Authority. Vagal Nerve Stimulation for Epilepsy and Depression; Final Evidence Report; Health Care Authority: Washington, DC, USA, 2020. 
115. Boon, P.; Vonck, K.; De Reuck, J.; Caemaert, J. Vagus nerve stimulation for refractory epilepsy. Seizure 2001, 10, 448-455. [CrossRef]

116. Boon, P.; Vonck, K.; Vandekerckhove, T.; D’Have, M.; Nieuwenhuis, L.; Michielsen, G.; Vanbelleghem, H.; Goethals, I.; Caemaert, J.; Calliauw, L.; et al. Vagus nerve stimulation for medically refractory epilepsy; efficacy and cost-benefit analysis. Acta Neurochir. 1999, 141, 447-453. [CrossRef] [PubMed]

117. Boon, P.; Vonck, K.; D’Have, M.; O’Connor, S.; Vandekerckhove, T.; De Reuck, J. Cost-benefit of vagus nerve stimulation for refractory epilepsy. Acta Neurol. Belg. 1999, 99, 275-280. [PubMed]

118. Boon, P.; D’Hav, M.; Van Walleghem, P.; Michielsen, G.; Vonck, K.; Caemaert, J.; De Reuck, J.; D’Havé, M. Direct medical costs of refractory epilepsy incurred by three different treatment modalities: A prospective assessment. Epilepsia 2002, 43, 96-102. [CrossRef]

119. Purser, M.; Mladsi, D.M.; Beckman, A.; Barion, F.; Forsey, J. Expected Budget Impact and Health Outcomes of Expanded Use of Vagus Nerve Stimulation Therapy for Drug-Resistant Epilepsy. Adv. Ther. 2018, 35, 1686-1696. [CrossRef]

120. Jennum, P.; Sabers, A.; Christensen, J.; Ibsen, R.; Kjellberg, J. Socioeconomic evaluation of vagus stimulation: A controlled national study. Seizure 2016, 42, 15-19. [CrossRef]

121. Ben-Menachem, E.; Hellström, K.; Verstappen, D. Analysis of direct hospital costs before and 18 months after treatment with vagus nerve stimulation therapy in 43 patients. Neurology 2002, 59, S44-S47. [CrossRef]

122. Bernstein, A.L.; Barkan, H.; Hess, T. Vagus nerve stimulation therapy for pharmacoresistant epilepsy: Effect on health care utilization. Epilepsy Behav. 2007, 10, 134-137. [CrossRef]

123. Bodin, E.; Le Moing, A.-G.; Bourel-Ponchel, E.; Querne, L.; Toussaint, P.; Berquin, P. Vagus nerve stimulation in the treatment of drug-resistant epilepsy in 29 children. Eur. J. Paediatr. Neurol. 2016, 20, 346-351. [CrossRef]

124. Burke, T.; Hughes, D.; Forsey, J.; Bunker, M.; Bhattacharya, D.; Smithson, W.H. A study of the impact of VNS on health care utilisation in England. Seizure 2016, 34, 12-17. [CrossRef]

125. Kalanithi, P.S.; Arrigo, R.T.; Tran, P.; Gephart, M.H.; Shuer, L.; Fisher, R.; Boakye, M. Rehospitalization and Emergency Department Use Rates Before and After Vagus Nerve Stimulation for Epilepsy: Use of State Databases to Provide Longitudinal Data Across Multiple Clinical Settings. Neuromodulation Technol. Neural Interface 2013, 17, 60-65. [CrossRef] [PubMed]

126. Helmers, S.L.; Duh, M.S.; Guérin, A.; Sarda, S.P.; Samuelson, T.M.; Bunker, M.T.; Olin, B.D.; Jackson, S.D.; Faught, E. Clinical and economic impact of vagus nerve stimulation therapy in patients with drug-resistant epilepsy. Epilepsy Behav. 2011, 22, 370-375. [CrossRef] [PubMed]

127. Révész, D.; Rydenhag, B.; Ben-Menachem, E. Complications and safety of vagus nerve stimulation: 25 years of experience at a single center. J. Neurosurg. Pediatr. 2016, 18, 97-104. [CrossRef] [PubMed] 